\section{Drought Avoidance in Katsura by Drought-induced Leaf Abscission and Rapid Refoliation}

\author{
Michael S. Dosmann'1, Jeffery K. Iles ${ }^{2}$, and William R. Graves ${ }^{3}$ \\ Department of Horticulture, Iowa State University, Ames, IA 50011-1100 \\ Additional index words. Cercidiphyllum japonicum, drought stress, woody landscape plants
}

Abstract. The limited use of the katsura tree (Cercidiphyllum japonicum Sieb. \& Zucc.) in the landscape may be due to its reputed, but uncharacterized, intolerance of drought. We examined the responses of katsura trees subjected to episodes of drought. Containergrown trees in a greenhouse were subjected to one of three irrigation treatments, each composed of four irrigation phases. Control plants were maintained under well-hydrated conditions in each phase. Plants in the multiple-drought treatment were subjected to two drought phases, each followed by a hydration phase. Plants in the single-drought treatment were exposed to an initial drought phase followed by three hydration phases. Trees avoided drought stress by drought-induced leaf abscission. Plants in the multiple- and single-drought treatments underwent a $63 \%$ and $34 \%$ reduction in leaf dry weight and a $60 \%$ and $31 \%$ reduction in leaf surface area, respectively. After leaf abscission, trees in the single-drought treatment recovered $112 \%$ of the lost leaf dry weight within 24 days. Leaf abscission and subsequent refoliation resulted in a temporary reduction in the leaf surface area : root dry weight ratio. After relief from drought, net assimilation rate and relative growth rate were maintained at least at the rates associated with plants in the control treatment. We conclude that katsura is a drought avoider that abscises leaves to reduce transpirational water loss. Although plants are capable of refoliation after water becomes available, to maintain the greatest ornamental value in the landscape, siting of katsura should be limited to areas not prone to drought.

The genus Cercidiphyllum is composed of two species native to eastern Asia. The common katsura ( $C$. japonicum) is endemic to Japan and China, although its native range in China has diminished to the degree that it is now classified as uncommon (Chien, 1992). As a landscape plant, the katsura is valued for its brilliant autumnal leaf color, picturesque form, slightly shaggy bark, and disease and pest resistance. The species recently gained celebrity by being named the Tree of the Year for 1997 by the International Dendrology Society (Andrews, 1998).

Despite these attributes, use of katsura in the landscape is rare. The reputation of katsura as a drought-intolerant tree may play a role in its limited usage. While experimental evidence pertaining to the drought intolerance of katsura is lacking, anecdotal references are common. Flint (1997) discusses the necessity for maintaining adequate soil moisture, as do others (Dirr, 1998; Wyman, 1971; Yiesla and Giles, 1992). Leaves on trees subjected to drought stress often become scorched and


for publication 4 Feb. 1999. Journal Paper no. J17962 of the Iowa Agriculture and Home Economics Experiment Station, Ames, Project no. 3229, and supported by Hatch Act and State of Iowa funds. The cost of publishing this paper was defrayed in part by the payment of page charges. Under postal regulations, this paper therefore must be hereby marked advertisement solely to indicate this fact.

${ }^{1}$ Graduate Research Assistant.

${ }^{2}$ Associate Professor; to whom reprint requests should be addressed; e-mail: iles@ iastate.edu ${ }^{3}$ Professor. after prolonged periods may senesce and abscise (personal observations). While drought may induce a significant amount of leaf abscission, refoliation after water becomes available has been observed, but not quantified (Kjelgren, 1994).

Soil moisture contents may vary considerably in natural and maintained landscapes as phase. The entire experiment was conducted three times. soils go through successive wet and dry cycles (Mazzoleni and Dickmann, 1988). Experiments simulating these conditions have been used to examine the response of trees subjected to cycles of drought (Liu and Dickmann, 1992; Mazzoleni and Dickmann, 1988). The objectives of our study were to examine the growth and morphological responses of katsura trees subjected to periods of drought and wellhydrated conditions. We quantified the degree of drought-induced leaf abscission and determined the refoliation capacity of trees after drought ended.

\section{Materials and Methods}

Plant material. On 4 Apr. 1997, 132, 2year-old, dormant, bare-root seedlings of katsura (Lawyer Nurseries, Plains, Mont.) were planted singly into $45-\mathrm{dm}^{3}$ Classic 816 (Nursery Supplies, Chambersburg, Pa.) nursery containers filled with Metro-Mix 700 (Scotts, Marietta, Ga.). We placed pieces of wire screen inside containers to prevent the loss of medium through drainage holes and put containers on a greenhouse bench under natural photoperiod (lat. $\left.42^{\circ} \mathrm{N}\right)$. Containers were irrigated with tap water ( $\mathrm{pH}$ of $8.74, \mathrm{EC}$ of $0.45 \mathrm{mS} \cdot \mathrm{cm}^{-1}$ ) as needed to keep the surface of the medium moist, and fertilized weekly with $\mathrm{N}$ at 155 $\mathrm{mg} \cdot \mathrm{L}^{-1}$ from Peters Excel all-purpose $21 \mathrm{~N}-$ 2.2P-16.6K fertilizer (Scotts, Marietta, Ga.) until treatments began.

Irrigation treatments. The study consisted of three irrigation treatments applied over four consecutive phases that simulated either drought or well-hydrated conditions (Fig. 1). In the control treatment, all phases were wellhydrated. The multiple-drought treatment consisted of drought in phases one (two cycles) and three (one cycle), and hydration in phases two and four. Plants in the single-drought



Fig. 1. Schematic of experimental protocol. Katsura trees assigned to control, single-drought, or multipledrought treatments were subjected to hydrated and/or drought conditions over four consecutive phases. Destructive harvests were conducted on the first day treatments began and the conclusion of each 
treatment were subjected to drought in phase one (two cycles), and hydrated conditions in phases two through four. For all treatments, phases one and three were considered complete when water was resupplied at the conclusion of a drought cycle, and lasted from 6 to 11 $\mathrm{d}$ and 4 to $6 \mathrm{~d}$, respectively. Phases two and four were arbitrarily assigned a duration of $9 \mathrm{~d}$. Destructive harvests were conducted on the first day treatments began and at the conclusion of each phase. For harvests where plants had been subjected to the same cumulative irrigation regimen, treatments were combined.

On 4 June 1997, 44 plants were selected for uniformity, randomly arranged on greenhouse benches and randomly assigned to one of the three treatments. There were 16,12 , and 12 plants assigned to the control, multiple- and single-drought treatments, respectively. The following day, phase one began and the first destructive harvest (of the remaining four plants) occurred. Stem length from the stem base to the shoot apex of each plant was measured. All plants were fertilized at the beginning of each phase with $\mathrm{N}$ at $155 \mathrm{mg} \cdot \mathrm{L}^{-1}$ from Peters Excel all-purpose $21 \mathrm{~N}-2.2 \mathrm{P}$ $16.6 \mathrm{~K}$ fertilizer (Scotts). Drought was imposed by withholding irrigation for the remainder of each drought cycle. A drought cycle was defined as complete when $50 \%$ of the plants subjected to drought wilted during either midday (1300 to $1500 \mathrm{HR}$ ) or morning (0600 to $0900 \mathrm{HR}$ ) hours in phases one and three, respectively. Phase one consisted of two drought cycles. When the first drought cycle was complete, containers were brought to container capacity with tap water and the second drought cycle began. Phase three consisted of one drought cycle. During hydration phases, plants were irrigated daily with tap water with the amount of water lost the previous $24 \mathrm{~h}$ due to evapotranspiration, as determined gravimetrically. Volumetric soil moisture content of the medium of each container was determined daily, before irrigation, with a Theta Probe (meter type HH1, sensor type ML1; Delta-T Devices Ltd., Cambridge, U.K.) soil moisture sensor at $6 \mathrm{~cm}$ below the soil surface.

Growth and leaf water potential. At each destructive harvest, we identified the youngest, fully expanded pair of leaves on each plant to be harvested. One of these leaves was used to determine the predawn (0300 to $0500 \mathrm{HR}$ ) leaf water potential $\left(\psi_{\mathrm{PD}}\right)$, measured with a pressure chamber(PMS Instruments, Corvallis, Ore.). The relationship between soil moisture content and $\mathrm{y}_{\mathrm{PD}}$ was described by using Deltagraph ${ }^{\circledR} 4.0$ (DeltaPoint, Monterey, Calif.) as the equation: $-\mathrm{MPa}=$ (soil moisture content $\left.^{-0.8976}\right)(0.09255) ; R^{2}=0.645$.

Stem diameter at $2.5 \mathrm{~cm}$ above the soil surface and stem length from the stem base to the shoot apex of each plant were measured. Internode length was determined by measuring the length between the node of the identified pair of leaves and the node immediately below it. From the remaining identified leaf, a $0.5-\mathrm{cm}^{2}$ disc was removed from the interveinal region of the basal half of the blade and dried at $67^{\circ} \mathrm{C}$ for 2 to $3 \mathrm{~d}$. Specific leaf weight was calculated by dividing the dry weight of each disk by its area. Because the drought treatments resulted in leaf desiccation and/or abscission, leaves (including petioles) were removed from the plants and designated as either viable or nonviable. Individual leaves that had not abscised and had $\approx 50 \%$ or more of their tissue undamaged were considered viable. The remaining leaves were classified as nonviable. All leaf data reported were obtained from viable leaves. Leaf surface area of viable leaves was measured by using an area meter (LI-3100; LI-COR, Lincoln, Nebr.). Roots were separated from their growth medium by hand in tap water. Dry weight of leaves, stems, and roots was determined after the material was dried for 2 to $3 \mathrm{~d}$ at $67^{\circ} \mathrm{C}$. The ratio of viable leaf surface area : root dry weight was calculated. Net assimilation rate and relative growth rate were determined for each treatment during each phase (Harper, 1977).

Experimental design and analysis of data. There were four single-plant replications (experimental units) within each harvest $\times$ treatment combination. The experiment was conducted three times, with the second and third experiments over time starting on 31 July 1997 and 6 Sept. 1997, respectively. Based upon a completely randomized design, data were analyzed by using the Statistical Analysis System (SAS Institute, Cary, N.C.). Within each harvest group, analyses of variance were performed by using the General Linear Model (PROC GLM), and treatment means that differed were separated according to the LSD test $(P \leq 0.05)$. Single-plant replicates one and two, and replicates three and four were combined and the averages used for statistical analysis of net assimilation rate and relative growth rate.

\section{Results and Discussion}

At soil moisture contents of $0.16 \mathrm{~m}^{3} \cdot \mathrm{m}^{-3}$ or higher, leaves did not abscise, but as moisture content decreased below $0.16 \mathrm{~m}^{3} \cdot \mathrm{m}^{-3}$, percentage leaf abscission increased linearly [percentage leaf abscission $=0.802-4.35$ (soil moisture content) $\left.R^{2}=0.488 ; P=0.0115\right]$. As drought severity increased, abscission of leaves progressed acropetally along shoots. During each drought phase, leaf dry weight and leaf surface area were reduced (Table 1). At the second harvest, leaf dry weight of plants in the drought treatments was $34 \%$ lower than that of control plants. Following drought in the third phase, leaf dry weight of plants in the multiple drought treatment was $63 \%$ lower than that of control plants. Leaf surface area of droughtstressed treatments was reduced by $31 \%$ and $60 \%$ following phases one and three, respectively. Soil matric potentials of less than -1.0 MPa induced leaf abscission and reduced total leaf area by $10 \%$ in two cultivars of hybrid poplar(Populus L.) (Mazzoleni and Dickmann, 1988), and black walnut trees (Juglans nigra L.) subjected to $\psi_{\mathrm{PD}}$ of -1 and $-2 \mathrm{MPa}$ abscised $\approx 35 \%$ and $\approx 62 \%$ of their leaves, respectively (Pallardy and Rhoads, 1993). Yet, while soil moisture content values of $0.16 \mathrm{~m}^{3} \cdot \mathrm{m}^{-3}$ induced leaf abscission in our study, values as low as $0.02 \mathrm{~m}^{3} \cdot \mathrm{m}^{-3}$ did not induce leaf abscission in cultivars of Freeman maple (Acer $\times$ freemanii E. Murray) (Zwack et al., 1998). Plant response, however, could have been influenced by differences in container media.

Abscission is a principal defense against drought (Addicott, 1982), and plants that shed leaves to avoid water deficits during water shortages have dehydration-sensitive tissues (Ludlow, 1989). Leaf loss abruptly decreases the evaporative surface and lowers transpirational water loss. Abscission of dehydrationsensitive leaves obviously decreased the katsura tree's demand for water and increased its internal water content. After drought-induced leaf abscission, soil water content in the drought treatments at the conclusion of nondrought phases was higher than in the controls (Table 1). At the conclusion of the study, drought treatments had higher (less negative) values of $\psi_{\mathrm{PD}}$ than did controls (Table 1). Similarly, Ginter-Whitehouse et al. (1983) determined that drought-induced leaf abscission in black walnut resulted in a conservation of water and an increased supply of water to the remaining leaves.

After drought ended, trees refoliated and leaf dry weight and leaf surface area increased (Table 1). At harvest five (22 to $24 \mathrm{~d}$ after rewatering), plants in the single-drought treatment had recovered $104 \%$ of their initial leaf dry weight and $96 \%$ of their initial leaf surface area. Black walnut also refoliated after droughtinduced leaf abscission, but the amount of new foliage never exceeded $5 \%$ of the original leaf area (Parker and Pallardy, 1985). While Pallardy and Rhoads (1993) observed refoliation after abscission in black walnut and sugar maple (Acer saccharum Marsh.), they found that the amount of new leaf area was inadequate to compensate for that lost. Based upon our observations, the high degree of refoliation found in katsura was probably associated with the rapid increase in lateral branch development, although we did not quantify this. Defoliation stimulates the development of lateral branches in other trees; a 2-fold increase in lateral branches was observed in hybrid poplar (Populus $\times$ euramericana (Dode) Guinier 'Negrito de Granada') (Bassman and Dickmann, 1982). Katsura is dimorphic, producing both long and short shoots. Apical dominance of the terminal long shoots inhibits the growth and development of the mature lateral branches below, maintaining them as short-shoot spurs. Titman and Wetmore (1955) found that removal of the auxin source, via decapitation of the terminal long shoot, resulted in the extension of the short-shoot spurs into juvenile long shoots. During our study, the inhibition of auxin transport associated with drought stress (Levitt, 1980) may have initiated the extension of the lateral spurs into juvenile long shoots, thus enabling plants to recover leaf area freely.

Drought reduced root dry weight of plants at the fourth and fifth harvests (Table 1). At harvest five, root dry weight of plants in the multiple- and single-drought treatments was $41 \%$ and $23 \%$ lower than that of control plants, respectively. Reduction in stem dry weight 
Table 1. Soil moisture content, predawn leaf water potential, dry matter partitioning, leaf surface area (LSA), and LSA : root dry weight ratio of katsura trees before treatment (harvest 1) and after being subjected to one of three irrigation treatments (control, multiple-drought, and single-drought), each composed of four phases of either hydrated or drought conditions. In harvests where the irrigation regimen of plants in multiple- and single-drought treatments did not differ, they are indicated as having been subjected to drought. Values are the means of 12 replicate trees obtained during three experiments.

\begin{tabular}{|c|c|c|c|c|c|c|c|c|}
\hline \multirow[b]{2}{*}{ Treatment } & \multirow{2}{*}{$\begin{array}{c}\text { Irrigation } \\
\text { phase }\end{array}$} & \multirow{2}{*}{$\begin{array}{c}\text { Soil moisture } \\
\text { content } \\
\left(\mathrm{m}^{3} \cdot \mathrm{m}^{-3}\right)\end{array}$} & \multirow{2}{*}{$\begin{array}{c}\text { Predawn leaf } \\
\text { water potential } \\
(-\mathrm{MPa})\end{array}$} & \multicolumn{3}{|c|}{ Dry wt (g) } & \multirow{2}{*}{$\begin{array}{l}\text { LSA } \\
\left(\mathrm{m}^{2}\right)\end{array}$} & \multirow{2}{*}{$\begin{array}{c}\text { LSA : root dry } \\
\text { wt ratio } \\
\left(\mathrm{cm}^{2} \cdot \mathrm{g}^{-1}\right) \\
\end{array}$} \\
\hline & & & & Leaf & Root & Stem & & \\
\hline \multicolumn{9}{|c|}{ Harvest 1 -before treatments } \\
\hline All & Hydrated & 0.31 & 0.29 & 34.2 & 31.0 & 58.6 & 0.84 & 345 \\
\hline $\begin{array}{l}\text { Control } \\
\text { Drought }\end{array}$ & $\begin{array}{l}\text { Hydrated } \\
\text { Droughted }\end{array}$ & $\begin{array}{l}0.27 \mathrm{a}^{\mathrm{z}} \\
0.11 \mathrm{~b}\end{array}$ & $\begin{array}{l}\text { Harvest } 2- \\
0.33 \mathrm{a} \\
0.88 \mathrm{~b}\end{array}$ & $\begin{array}{l}\text { hase on } \\
36.1 \mathrm{a} \\
23.7 \mathrm{~b}\end{array}$ & $\begin{array}{l}30.1 \mathrm{a} \\
30.1 \mathrm{a}\end{array}$ & $\begin{array}{l}64.8 \mathrm{a} \\
53.5 \mathrm{~b}\end{array}$ & $\begin{array}{l}0.81 \mathrm{a} \\
0.56 \mathrm{~b}\end{array}$ & $\begin{array}{l}381 \mathrm{a} \\
278 \mathrm{~b}\end{array}$ \\
\hline $\begin{array}{l}\text { Control } \\
\text { Drought }\end{array}$ & $\begin{array}{l}\text { Hydrated } \\
\text { Hydrated }\end{array}$ & $\begin{array}{l}0.25 \mathrm{~b} \\
0.29 \mathrm{a}\end{array}$ & $\begin{array}{l}\text { Harvest } 3- \\
0.32 \mathrm{a} \\
0.32 \mathrm{a}\end{array}$ & $\begin{array}{l}\text { hase tw } \\
36.1 \mathrm{a} \\
26.4 \mathrm{~b}\end{array}$ & $\begin{array}{l}37.2 \mathrm{a} \\
29.2 \mathrm{a}\end{array}$ & $\begin{array}{l}69.4 \mathrm{a} \\
62.3 \mathrm{a}\end{array}$ & $\begin{array}{l}0.89 \mathrm{a} \\
0.61 \mathrm{~b}\end{array}$ & $\begin{array}{l}418 \mathrm{a} \\
358 \mathrm{a}\end{array}$ \\
\hline $\begin{array}{l}\text { Control } \\
\text { Multiple drought } \\
\text { Single drought }\end{array}$ & $\begin{array}{l}\text { Hydrated } \\
\text { Droughted } \\
\text { Hydrated }\end{array}$ & $\begin{array}{l}0.20 \mathrm{~b} \\
0.09 \mathrm{c} \\
0.24 \mathrm{a}\end{array}$ & $\begin{array}{c}\text { Harvest 4-a } \\
0.33 \mathrm{a} \\
1.50 \mathrm{~b} \\
0.29 \mathrm{a}\end{array}$ & $\begin{array}{c}\text { hase thr } \\
42.4 \mathrm{a} \\
15.6 \mathrm{c} \\
32.8 \mathrm{~b}\end{array}$ & $\begin{array}{l}40.8 \mathrm{a} \\
28.9 \mathrm{~b} \\
34.2 \mathrm{ab}\end{array}$ & $\begin{array}{l}75.4 \mathrm{a} \\
65.1 \mathrm{a} \\
69.0 \mathrm{a}\end{array}$ & $\begin{array}{l}0.90 \mathrm{a} \\
0.36 \mathrm{c} \\
0.72 \mathrm{~b}\end{array}$ & $\begin{array}{l}328 \mathrm{a} \\
213 \mathrm{~b} \\
295 \mathrm{a}\end{array}$ \\
\hline $\begin{array}{l}\text { Control } \\
\text { Multiple drought } \\
\text { Single drought }\end{array}$ & $\begin{array}{l}\text { Hydrated } \\
\text { Hydrated } \\
\text { Hydrated }\end{array}$ & $\begin{array}{l}0.16 \mathrm{c} \\
0.30 \mathrm{a} \\
0.20 \mathrm{~b}\end{array}$ & $\begin{array}{l}\text { Harvest 5-c } \\
0.47 \mathrm{~b} \\
0.32 \mathrm{a} \\
0.38 \mathrm{a}\end{array}$ & $\begin{array}{l}\text { hase for } \\
49.0 \mathrm{a} \\
20.8 \mathrm{c} \\
35.5 \mathrm{~b}\end{array}$ & $\begin{array}{l}46.3 \mathrm{a} \\
27.3 \mathrm{c} \\
35.5 \mathrm{~b}\end{array}$ & $\begin{array}{l}98.5 \mathrm{a} \\
68.8 \mathrm{~b} \\
81.2 \mathrm{~b}\end{array}$ & $\begin{array}{l}1.10 \mathrm{a} \\
0.48 \mathrm{c} \\
0.81 \mathrm{~b}\end{array}$ & $\begin{array}{l}273 \mathrm{a} \\
252 \mathrm{a} \\
309 \mathrm{a}\end{array}$ \\
\hline
\end{tabular}

${ }^{\mathrm{z}}$ Mean separation within columns and harvests by analysis of variance and LSD, $P \leq 0.05$.

also was observed (Table 1). At the final harvest, stem dry weight of multiple- and single-drought treatments was reduced by $30 \%$ and $18 \%$, respectively. Drought reduced root elongation in white oak (Quercus alba L.) and post oak (Quercus stellata Wangenh.), and root elongation and stem dry weight in black walnut and red oak (Quercus rubra L.) (Pallardy and Rhoads, 1993). Manual defoliation also reduced root and stem dry weight in tuliptree (Liriodendron tulipifera L.) (Madgwick, 1975). The reduction in root and stem dry weight in katsura may have resulted from the inhibition of growth associated with a limited supply of water and decreased photosynthate due to leaf abscission, and depleted root and stem reserves associated with refoliation.

Because of leaf abscission, the ratio of leaf surface area : root dry weight in plants completing a drought cycle was lower than that in plants subjected to well-hydrated conditions at harvests two and four (Table 1). However, after droughted plants had refoliated during a 9-d hydration phase, ratios were similar in all treatments. The temporary reduction in leaf surface area : root dry weight ratio resulted in a more favorable balance between the waterabsorbing (roots) and water-losing (leaves) tissues. This change in the ratio suggests that once drought ends, katsura allocates more carbon to the production of new leaves than to production of new root and stem tissue.

During drought phases, net assimilation rate and relative growth rate of drought treatments were negative (Table 2), probably because of leaf abscission. During phases two and four, net assimilation rates were positive in all treatments and did not differ, indicating that trees that had previously been subjected to drought could assimilate carbon at the same rate as controls. In phase three, plants in the single-drought treatment had a higher net assimilation rate than did control plants, indicating that during recovery, the former were temporarily more efficient at assimilating carbon than were the latter. Relative growth rate of plants in all treatments differed only if they were irrigated differently during that phase (Table 2). While net assimilation rate in the single-drought treatment increased temporarily during phase three, the relative growth rate did not. Although the values remained positive, net assimilation rate and relative growth rate also decreased in red maple (Acer rubrum L.), pawpaw [Asimina triloba (L.) Dunal], black tupelo (Nyssa sylvatica Marsh.), and bald cypress [Taxodium distichum (L.) Rich.] subjected to drought (Nash and Graves, 1993). Paralleling our observations of katsura trees recovering from defoliation, Madgwick (1975) found that both the photosynthetic efficiency of tuliptree leaves, expressed as unit leaf rate, and the rate of leaf production increased with severity of defoliation.

Drought decreased stem diameter and stem elongation, although plants in the single- and multiple-drought treatments did not differ from one another. At the conclusion of the study, stem diameter was reduced by $16.4 \%$ and $15.7 \%$ in the multiple- and single-drought treatments, respectively. Control treatments grew an additional $43 \mathrm{~cm}$, whereas single- and multiple-drought treatments grew only 29 and $28 \mathrm{~cm}$, respectively; drought reduced stem elongation $\approx 34 \%$. After 3 weeks of severe drought, stem elongation of eastern cottonwood (Populus deltoides Marsh.) seedlings was reduced by $\approx 13 \%$ (Kelliher et al., 1980). Mazzoleni and Dickmann (1988) found that, while drought reduced height growth in 'Eugenei' hybrid poplar by $\approx 17 \mathrm{~cm}, 10 \mathrm{~d}$ of irrigation at the conclusion of the study led to a flush in height growth of $\approx 12 \mathrm{~cm}$. In our study, 22 to 24 d of irrigation following drought in a single-drought treatment, resulted in an increase in height growth of only $1 \mathrm{~cm}$. No differences among treatments were observed in internode length and specific leaf weight.

Table 2. Net assimilation rate (NAR) and relative growth rate (RGR) of katsura trees subjected to one of three irrigation treatments (control, multiple-drought, and single-drought), each composed of four irrigation phases that simulated either hydrated or drought conditions. In phases where the irrigation regimen of plants in multiple- and single-drought treatments did not differ, they are indicated as having been subjected to drought. Values are the means of six replicate trees obtained during three experiments.

\begin{tabular}{|c|c|c|c|}
\hline Treatment & $\begin{array}{c}\text { Irrigation } \\
\text { phase }\end{array}$ & $\begin{array}{c}\text { NAR } \\
\left(\mu \mathrm{g} \cdot \mathrm{cm}^{-2} \cdot \mathrm{d}^{-1}\right)\end{array}$ & $\begin{array}{c}\mathrm{RGR} \\
\left(\mathrm{mg} \cdot \mathrm{g}^{-1} \cdot \mathrm{d}^{-1}\right)\end{array}$ \\
\hline \multicolumn{4}{|c|}{ Phase one } \\
\hline Control & Hydrated & $60 a^{z}$ & $5.6 \mathrm{a}$ \\
\hline Drought & Droughted & $-97 \mathrm{~b}$ & $-2.3 b$ \\
\hline \multicolumn{4}{|c|}{ Phase two } \\
\hline Control & Hydrated & $82 \mathrm{a}$ & $9.7 \mathrm{a}$ \\
\hline Drought & Hydrated & $62 \mathrm{a}$ & $3.1 \mathrm{a}$ \\
\hline \multicolumn{4}{|c|}{ Phase three } \\
\hline Control & Hydrated & $143 \mathrm{~b}$ & $13.1 \mathrm{a}$ \\
\hline Multiple drought & Droughted & $-144 \mathrm{c}$ & $-1.7 b$ \\
\hline Single drought & Hydrated & $257 \mathrm{a}$ & $18.7 \mathrm{a}$ \\
\hline \multicolumn{4}{|c|}{ Phase four } \\
\hline Control & Hydrated & $198 \mathrm{a}$ & $13.7 \mathrm{a}$ \\
\hline Multiple drought & Hydrated & $63 \mathrm{a}$ & $7.6 \mathrm{a}$ \\
\hline Single drought & Hydrated & $115 \mathrm{a}$ & $10.1 \mathrm{a}$ \\
\hline
\end{tabular}

${ }^{2}$ Mean separation within columns and phases by analysis of variance and LSD, $P \leq 0.05$. 
Ludlow (1989) stated that drought-induced leaf abscission reduces photosynthesis and leads to a slow recovery once stress is relieved. While leaf shedding probably reduced photosynthate production, we found that net assimilation rate and relative growth rate were maintained and net assimilation rate temporarily increased after drought ended. Katsura also appears to have a heightened capacity for refoliation, perhaps contributing to an enhanced recovery, because we found that trees replaced $112 \%$ of the leaf dry weight lost within $24 \mathrm{~d}$.

As a means of avoiding drought stress, katsura abruptly reduces transpirational water loss by shedding leaves of lower photosynthetic activity. This leads to the conservation of water for the whole tree and an increased supply of water to the remaining leaves. While katsura may postpone damage associated with drought on a short-term basis, the long-term costs of repeated drought stress and droughts of longer duration are likely to be severe. In addition to the loss of photosynthate associated with leaf abscission, additional reductions in root dry weight, stem diameter and stem elongation may occur. The elongation of short-shoot spurs into juvenile long shoots may temporarily decrease the sexual reproductive capacity of established trees, since flowers are produced only on mature spur branches. The variability in growth habit (single stem versus multistem) of katsura trees has been associated with provenance and gender, although only anecdotally. This variability may be equally explained by the interplay of dimorphism and auxin-regulation (perhaps due to drought) in young trees. Because our conclusions are based only on the response of young plants, further study of the effects of drought on mature trees is warranted. To date, no genotypes of katsura have been selected for resistance to drought or other forms of environmental stress. The identification and selection of genotypes that tolerate drought by means other than leaf abscission would strengthen the appeal of this ornamental landscape tree.

\section{Literature Cited}

Addicott, F.T. 1982. Abscission. Univ. California Press, Los Angeles.

Andrews, S. 1998. Tree of the year: Cercidiphyllum japonicum. Intl. Dendrol. Soc. Yrbk. 1997:1746.

Bassman, J.H. and D.I. Dickmann. 1982. Effects of defoliation in the developing leaf zone on young Populus Xeuramericana plants. I: Photosynthetic physiology, growth, and dry weight partitioning. For. Sci. 28:599-612.

Chien, H. 1992. Cercidiphyllum japonicum Sieb. et Zucc., p. 212-213. In: L. Fu and J. Jin (eds.). China plant red data book: Rare and endangered plants. Science Press, New York.

Dirr, M.A. 1998. Manual of woody landscape plants: Their identification, ornamental characteristics, culture, propagation, and uses. $5^{\text {th }}$ ed. Stipes, Champaign, Ill.

Flint, H.L. 1997. Landscape plants for eastern North America. $2^{\text {nd }}$ ed. Wiley, New York.

Ginter-Whitehouse, D.L., T.M. Hinckley, and S.G. Pallardy. 1983. Spatial and temporal aspects of water relations of three tree species with different vascular anatomy. For. Sci. 29:317-329.

Harper, J.L. 1977. Population biology of plants. Academic, London.

Kelliher, F.M., M.B. Kirkham, and C.G. Tauer. 1980. Stomatal resistance, transpiration, and growth of drought-stressed eastern cottonwood. Can. J. For. Res. 10:447-451.

Kjelgren, R. 1994. Landscape tree evaluation in the intermountain west. Landscape Plant News 5:34.
Levitt, J. 1980. Responses of plants to environmental stresses. vol. II: Water, radiation, salt, and other stresses. $2^{\text {nd }}$ ed. Academic, New York.

Liu, Z. and D.I. Dickmann. 1992. Responses of two hybrid Populus clones to flooding, drought, and nitrogen availability. I: Morphology and growth. Can. J. Bot. 70:2265-2270.

Ludlow, M.M. 1989. Strategies of response to water stress, p. 269-281. In: K.H. Kreeb, H. Richter, and T.M. Hinckley (eds.). Structural and functional responses to environmental stresses. SPB Academic, The Hague, Netherlands.

Madgwick, H.A.I. 1975. Effects of partial defoliation on the growth of Liriodendron tulipifera $\mathrm{L}$. seedlings. Ann. Bot. 39:1111-1115.

Mazzoleni, S. and D.I. Dickmann. 1988. Differential physiological and morphological responses of two hybrid Populus clones to water stress. Tree Physiol. 4:61-70.

Nash, L.J. and W.R. Graves. 1993. Drought and flood stress effects on plant development and leaf water relations of five taxa of trees native to bottomland habitats. J. Amer. Soc. Hort. Sci. 118:845-850.

Pallardy, S.G. and J.L. Rhoads. 1993. Morphological adaptations to drought in seedlings of deciduous angiosperms. Can. J. For. Res. 23:17661774.

Parker, W.C. and S.G. Pallardy. 1985. Droughtinduced leaf abscission and whole-plant drought tolerance of seedlings of seven black walnut families. Can. J. For. Res. 15:818-821.

Titman, P.W. and R.H. Wetmore. 1955. The growth of long and short shoots in Cercidiphyllum. Amer. J. Bot. 42:364-372.

Wyman, D. 1971. Wyman's gardening encyclopedia. Macmillan, New York.

Yiesla, S.A. and F.A. Giles. 1992. Shade trees for the central and northern United States and Canada. Stipes, Champaign, Ill.

Zwack, J.A., W.R. Graves, and A.M. Townsend 1998. Leaf water relations and plant development of three Freeman maple cultivars subjected to drought. J. Amer. Soc. Hort. Sci. 123:371-375. 